\title{
STRATEGI PENGENDALIAN PEMANFAATAN LAHAN SEKITAR KAWASAN KALIMALANG KOTA BEKASI SECARA BERKELANJUTAN
}

\author{
${ }^{1}$ YULIA ASYIAWATI, ${ }^{2}$ NUR EVY OKTAVYA \\ 1,2 Prodi Perencanaan Wilayah dan Kota, \\ Fakultas Teknik, Universitas Islam Bandung, \\ Jl. Tamansari No. 1 Bandung 40116 \\ e-mail: 1viedikta@yahoo.com, ${ }^{2}$ yulia_asyiawati@yahoo.com
}

\begin{abstract}
ABSTRAK
Sejalan dengan perkembangan penduduk suatu kota, akan meningaktkan kebutuhan lahan untuk memenuhi kebutuhan masyarakat, diantaranya adalah untuk kebutuhan permukiman, pengembangan kegiatan sosial dan ekonomi masyarakat. Di sisi lain ketersediaan lahan yang ada tetap, sehingga hal ini mengakibatkan banyak terjadi ali fungsi peruntukan lahan. Demikian juga halnya yang terjadi di Kawasan Kalimalang Kota Bekasi.

Kawasan Kalimalang Kota Bekasi yang terdapat di tengah-tengah Kota Bekasi memupunyai fungsi sebagai kawasan yang berfungsi lindung. Pada kenyataannya pada saat ini, kawasan Kalimalang secara sporadis dimanfaatkan oleh masyarakat untuk permukiman, perdagangan serta penggunaan jasa lainnya seerti seperti jasa bengkel. Semua kegiatan sosial ekonomi masyarakat yang terdapat di Kawasan kalimalang, membuang limbahnya ke Kalimalang. Hal ini mengakibatkan terjadinya penurunan kualitas air sungai Kalimalang yang merupakan salah satu sumber air baku untuk memenuhi kebutuhan air bersih di Kota Bekasi. Berdasarkan Kalimalang Bekasi dimanfaatkan sebagai sumber air baku di Kota Bekasi ialah Kalimalang. Oleh karena itu perlu dilakukan kajian untuk mengendalikan pemanfaatan lahan di sekitar Kawasan Kalimalang Kota Bekasi agar dapat mewujudkan kondisi lingkungan yang lestari sesuai rencana tata ruang.

Tujuan yang diharapkan dari studi ini (1) identifikasi karakteristik masyarakat yang tinggal di kawasan studi; (2) identifikasi faktor yang mengalami penyimpangan penggunaan lahan; dan (3) identifikasi faktor yang mempengaruhi penggunaan lahan. Metode aanalisis yang dilakukan untuk mencapai tujuan tersebut adalah metode super impose antara pemanfaatan lahan eksisting dengan rencana tata ruang dana analisis kesesuaian peruntukan lahan; analisis korelasi kontingensi untuk melihat hubungan antara pemanfaatan lahan dengan kondisi masyarakat, serta analisis deskriptif untuk memberikan gambaran tentang kebijakan tata ruang Kota Bekasi.

Dengan menggunakan analisis tersebut, diperoleh hasil bahwa pemanfaatan lahan di Kawasan Kalimalang mengalami pergeseran peruntukan sebesar 65,80 \% dari luas lahan kawasan yaitu $123.938 \mathrm{ha}$. Hal ini disebabkan karena rendahnya tingkat pendapatan masyarakat dan tingginya aksesibiltas dari kawasan ini menuju ke tempat kerja masyarakat. Untuk mengatasi kondisi tersebut, kawasan kalimalang harus dikendalikan pemanfaatannya dengan mengembalikan fungsi kawasan sebagai kawasan yang berfungsi lindung. Oleh karena itu langkah yang dilakukan adalah dengan
\end{abstract}


merelokasi masyarakat yang tinggal di kawasan studi dan menata ulang Kawasan kalimalang sesuai dengan daya dukung dan daya tampung kawasan. Hal ini dilakukan untuk dapat mewujudkan pemanfaatan lahan berkelanjutan di Kawasan Kalimalang.

Kata Kunci : Pengendalian Pemanfaatan lahan, Pemanfaatan lahan, kaewasan berfungsi lindung, Pemanfaatan lahan berkelanjutan

\section{Pendahuluan}

Manusia memiliki berbagai jenis kebutuhan, baik kebutuhan primer maupun kebutuhan sekunder. Dalam memenuhi kebutuhannya tersebut, manusia memanfaatkan sumber daya alam yang tersedia. Salah satu sumber daya yang dibutuhkan ialah lahan atau ruang. lahan memiliki sifat tetap sehingga perlunya perencanaan yang tepat agar tidak terjadi pemanfaatan lahan yang tidak terkendali. Berdasarkan Peraturan Pemerintah Republik Indonesia Nomor 16 Tahun 2004 Tentang Penatagunaan Tanah pada Pasal 1 alenia 4 Pemanfaatan tanah atau lahan adalah kegiatan untuk mendapatkan nilai tambah tanpa mengubah wujud fisik penggunaan tanahnya. Pasal 2 Penatagunaan tanah berasaskan keterpaduan, berdayaguna dan berhasilguna, serasi, selaras, seimbang, berkelanjutan, keterbukaan, persamaan, keadilan dan perlindungan hukum.

Kota Bekasi merupakan salah satu kota di Provinsi Jawa Barat yang merupakan wilayah hinterland DKI Jakarta sehingga mengalami perkembangan yang sangat pesat. Tingginya pertumbuhan penduduk mengakibatkan pemanfaatan ruang di Kota Bekasi menjadi kurang terkendali. Salah satunya adalah pemanfaatan ruang di sekitar Kalimalang Kota Bekasi. Kalimalang memiliki kedalaman sekitar 2,5 meter dan lebar 24 meter sehingga jika mengacu pada Peraturan Pemerintah Nomor 38 Tahun 2011 tentang Sungai diatas seharusnya memiliki sempadan sungai 15 (lima belas) meter dari tepi kiri dan kanan.

Kawasan Kalimalang merupakan area konservasi atau kawasan lindung. Sementara fenomena yang ada disekitar area yang seharusnya menjadi sempadan sungai saat ini lebih banyak bangunan bangunan dengan berbagai fungsi seperti perumahan, permukiman kumuh, pusat perbelanjaan, perkantoran, ditambah lagi adanya penggunaan lahan pinggiran sungai yang difungsikan sebagai infrastruktur jalan dan banyak aktifitas lainnya. Sementara salah satu permasalahan Kota Bekasi ialah minimnya ruang terbuka hijau jika mengacu pada Peraturan Presiden no 26 tahun 2007 Pasal 29 sebuah kota harus memiliki ruang terbuka hijau sebanyak $30 \%$ dari luas wilayah kota.

Tingginya angka pertumbuhan penduduk suatu kota menutut untuk tersedianya lahan sebagai wadah aktivitas penduduk kota tersebut sehingga pemanfaatan ruang untuk pemenuhan kebutuhan penduduk pun menjadi tidak terkendali. Tingkat pendapatan masyarakat yang relatif rendah mengakibatkan masyarakat membangun-bangunan secara ilegal dikawasan Kalimalang.

Lingkungan yang baik dan sehat akan menciptakan energi yang positif bagi masyarakat sekitar Kota Bekasi. Berdasarkan isu yang diangkat pada latar belakang ini penulis mencoba membuat suatu "Kajian Pengendalian Pemanfaatan Lahan Sekitar Kawasan Kalimalang di Kota Bekasi Secara Berkelanjutan" kajian tersebut akan memberikan konsep tepian sungai yang 
dijadikan ruang publik berupa ruang terbuka hijau (RTH) ataupun hutan kota yang dapat difungsikan sebagai kawasan lindung, konsep penataan tersebut bertujuan agar dapat memenuhi kebutuhan manusia dengan mempertahankan dan meningkatkan kualitas lingkungan serta melestarikan sumber daya alam yaitu sungai.

Tujuan dari penyusunan studi kajian pengendalian pemanfaatan lahan sekitar Kalimalang Kota Bekasi secara berkelanjutan ini adalah : 1) Identifikasi karakteristik masyarakat yang tinggal di kawasan studi; 2) Identifikasi faktor yang mengalami penyimpangan penggunaan lahan; 3) Identifikasi faktor yang mempengaruhi penggunaan lahan.

\section{Tinjauan Pustaka}

\section{Tata Ruang}

Perencanaan adalah hal memilih dan menghubungkan fakta-fakta serta hal membuat dan menggunakan dugaandugaan mengenai masa yang akan datang dalam hal menggambarkan dan merumuskan kegiatan-kegiatan yang diusulkan, yang dianggap dianggap perlu untuk mencapai mencapai hasil yang diinginkan (Moekijat, 1980; 431-432).

Pemanfaatan Ruang adalah upaya untuk mewujudkan struktur ruang dan pola ruang sesuai dengan rencana tata ruang melalui penyusunan dan pelaksanaan program beserta pembiayaannya. (Undang-Undang Nomor 26 Tahun 2007).

Pengendalian pemanfaatan ruang adalah sebagai usaha untuk menjaga kesesuaian pemanfaatan ruang dengan fungsi ruang yang ditetapkan rencana tata ruang. (Undang-Undang Nomor 26 Tahun 2007).

Peraturan zonasi merupakan ketentuan yang mengatur pemanfaatan ruang dan unsur-unsur pengendalian yang disusun untuk setiap zona peruntukan sesuai dengan rencana rinci tata ruang. Peraturan Zonasi (Zoning Regulation) adalah ketentuan yang mengatur tentang klasifikasi zona, pengaturan lebih lanjut mengenai pemanfaatan lahan, dan prosedur pelaksanaan pembangunan. (Barnet, 1982).

\section{Pembangunan Berkelanjutan}

Konsep Sustainable

Development memberikan wacana barumengenai pentingnya melestarikan lingkungan alam di masa depan, generasi yang akan datang pembangunan yang memenuhi kebutuhan sekarang tanpa mengkompromikan kemampuan generasi mendatang untuk memenuhi kebutuhan mereka sendiri. (Brundtland 1987), pembangunan berkelanjutan adalah bagaimana memperbaiki kehancuran lingkungan tanpa mengorbankan kebutuhan pembangunan ekonomi dan keadilan sosial.

Pembangunan berkelanjutan terdiri dari tiga tiang utama yakni ekonomi, sosial, dan lingkungan yang saling bergantung dan memperkuat. Ketiga aspek tersebut tidak bisa dipisahkan satu sama lain, karena ketiganya menimbulkan hubungan sebab-akibat.

Hubungan ekonomi dan sosial diharapkan dapat menciptakan hubungan yang adil (equitable). Hubungan antara ekonomi dan lingkungan diharapkan dapat terus berjalan (viable). Sedangkan hubungan antara sosial dan lingkungan bertujuan agar dapat terus bertahan (bearable). Ketiga aspek yaitu aspek ekonomi, sosial, dan lingkungan akan menciptakan kondisi berkelanjutan (sustainable).

\section{Hasil Penelitian dan Pembahasan}

Kawasan Kalimalang yang mempunyai luas 123.938 ha, secara administrasi terletak di Kelurahan Kayuringin (Kecamatan Bekasi Barat) dan Kelurahan Jakasampurna 
Kecamatan Bekasi Selatan), dengan batas administrasi sebagai berikut :

Batas Utara : Kelurahan Bintara

Batas Timur : Kelurahan Marga Jaya
Batas Selatan : Kelurahan Pekayon Jaya dan Jatibening Baru

Batas Barat : Jakarta Timur

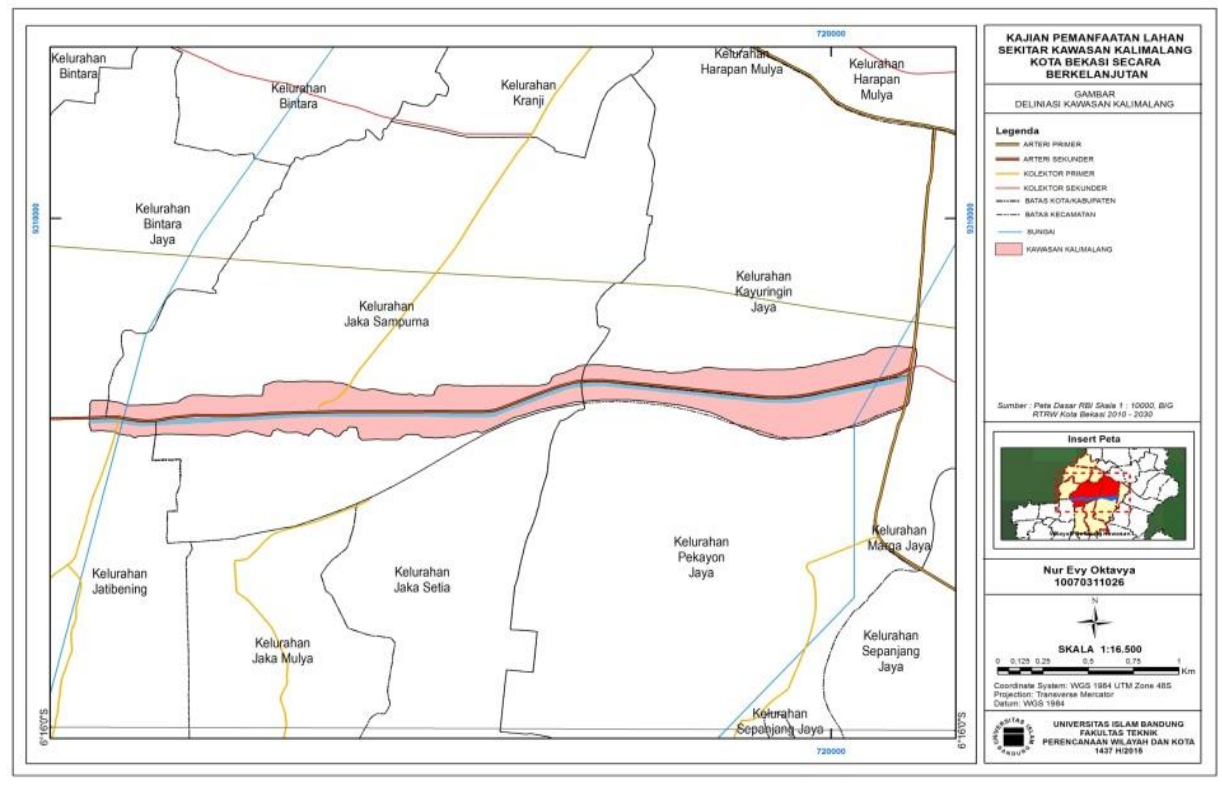

Gambar 1 Peta Lokasi Penelitian

Daya Dukung dan Daya Tampung Lahan

Daya dukung lahan dilakukan dengan tujuan untuk mennetukan kemampuan lahan untuk menampung kegiatan yang ada di atasnya. Berdasarkan hasil analisis yang dilakukan dengan mempertimbangkan kondisi fisik lahan yang terdapat di kawasan penelitian, diperoleh hasil bahwa kawasan Kalimalang mempunyai daya dukung rendah sampai dengan tinggi, dengan luas lahan yang sesuai dimanfaatkan untuk pengembangan kegiatan (daya dukung sedang sampai tinggi) adalah 88,995 ha. Kawasan tersebut mempunyai jarak > 15 meter dari Kalimalang, sehingga relatif aman untuk dikembangkan sebagai kawasan pengembangan terbatas. Dari luas lahan tersebut, ditentukan daya tampung ruang. Berdasarkan analisis yang dilakukan diperoleh hasil bahwa Kawasan Kalimalang hanya mampu menampung 4.272 jiwa, sementara jumlah penduduk yang tinggal di kawasan ini pada saat ini adalah 4.850 jiwa. Oleh karena itu perlu dilakukan penanganan relokasi penduduk yang tinggal di sekitar kawasan Kalimalang, agar pemanfaatan lahan sesuai dengan daya dukung dan daya tampungnya.

\section{Analisis Kesesuaian Peruntukan Lahan}

Analisis kesesuaian peruntukan lahan dilakukan dengan tujuan agar pemanfaatan lahan di Kawasan Kalimalang dimanfaatkan sesuai dengan peruntukkannya. Hal ini dilakukan dengan menggunakan analisis super impose dari kondisi fisik lahan, mencakup kondisi topografi, kemiringan lahan, jenis tanah, kondisi tekstur tanah, curah hujan). Hasil yang diperoleh adalah bahwa kawasan Kalimalang sesuai peruntukkannnya untuk kawasan yang berfungsi lindung seperti ruang terbuka hijau, kawasan permukiman terbatas. Beradsarkan hasil ini, dilakukan overlay antara penggunaan 
lahan eksisting dengan rencana pola ruang. Dari analisis overlay yang dilakukan diperoleh hasil sebagaimana dapat dilihat pada tabel berikut :

Tabel 1 Hasil Superimpose Pemanfaatan Lahan

\begin{tabular}{|c|c|c|c|c|c|c|}
\hline No & $\begin{array}{c}\text { Penggunaan } \\
\text { Lahan } \\
\text { Eksisting }\end{array}$ & $\begin{array}{c}\text { Pola } \\
\text { Ruang } \\
\text { RDTR } \\
\end{array}$ & Luasan & $\begin{array}{c}\text { Hasil } \\
\text { Overlay }\end{array}$ & Keterangan & $\begin{array}{c}\text { Dampak } \\
\text { Lingkungan }\end{array}$ \\
\hline 1 & $\begin{array}{c}\text { Perdagangan dan } \\
\text { Jasa }\end{array}$ & Fungsi Jasa & 1,054 & Tidak & $\begin{array}{l}\text { Kawasan } \\
\text { Budidaya }\end{array}$ & - \\
\hline 2 & $\begin{array}{c}\text { Perdagangan dan } \\
\text { Jasa }\end{array}$ & $\begin{array}{c}\text { Fungsi } \\
\text { Perdagangan }\end{array}$ & 18,662 & Tidak & $\begin{array}{l}\text { Kawasan } \\
\text { Budidaya }\end{array}$ & - \\
\hline 3 & Perkantoran & Fungsi Jasa & 0,370 & Ya & $\begin{array}{l}\text { Kawasan } \\
\text { Budidaya }\end{array}$ & $\begin{array}{l}\text { Mengalami alih fungsi } \\
\text { namun tidak } \\
\text { menciptakan dampak } \\
\text { lingkungan }\end{array}$ \\
\hline 4 & Industri & $\begin{array}{c}\text { Fungsi } \\
\text { Perdagangan }\end{array}$ & 2,454 & Ya & $\begin{array}{l}\text { Kawasan } \\
\text { Budidaya }\end{array}$ & - \\
\hline 5 & Kolam Renang & $\begin{array}{c}\text { Fungsi } \\
\text { Perdagangan }\end{array}$ & 0,277 & Ya & $\begin{array}{l}\text { Kawasan } \\
\text { Budidaya }\end{array}$ & $\begin{array}{c}\text { Mengalami alih fungsi } \\
\text { tetapi tidak } \\
\text { menciptakan dampak } \\
\text { penurunan kualitas } \\
\text { lingkungan namun } \\
\text { akan menimbulkan } \\
\text { dampak sosial seperti : } \\
\text { tidak tersediannya } \\
\text { lahan rekreasi dan } \\
\text { tempat bermain. }\end{array}$ \\
\hline 6 & $\begin{array}{l}\text { Ruang Terbuka } \\
\text { Hijau (RTH) }\end{array}$ & $\begin{array}{c}\text { Fungsi } \\
\text { Perdagangan }\end{array}$ & 0,932 & Ya & $\begin{array}{l}\text { Kawasan } \\
\text { Budidaya }\end{array}$ & $\begin{array}{l}\text { Mengalami alih fungsi } \\
\text { namun kondisi } \\
\text { eksisting harus } \\
\text { dipertahankan karena } \\
\text { permasalahan Kota } \\
\text { Bekasi yang minim } \\
\text { RTH dan jika diubah } \\
\text { kondisi eksisitingnya } \\
\text { akan menimbulkan } \\
\text { dampak sosial seperti } \\
\text { tidak adanya lahan } \\
\text { untuk bermain dan } \\
\text { berkurangnya daerah } \\
\text { resapan air yang akan } \\
\text { menimbulkan bencana } \\
\text { banjir. }\end{array}$ \\
\hline 7 & Pendidikan & $\begin{array}{c}\text { Fungsi } \\
\text { Perdagangan }\end{array}$ & 2,721 & Ya & $\begin{array}{l}\text { Kawasan } \\
\text { Budidaya }\end{array}$ & $\begin{array}{c}\text { Mengalami alih fungsi } \\
\text { namun tidak } \\
\text { menciptakan dampak } \\
\text { lingkungan, kondisi } \\
\text { eksisting merupakan } \\
\text { suatu sarana yang } \\
\text { dapat menciptakan } \\
\text { kualitas SDM di } \\
\text { kawasan Kalimalang } \\
\text { menjadi lebih baik dan } \\
\text { memberikan dampak } \\
\text { positif terhadap } \\
\text { lingkungan sekitar } \\
\text { sehingga harus } \\
\text { dipertahankan. }\end{array}$ \\
\hline 8 & Pergudangan & $\begin{array}{c}\text { Fungsi } \\
\text { Perdagangan }\end{array}$ & 0,500 & Ya & $\begin{array}{l}\text { Kawasan } \\
\text { Budidaya }\end{array}$ & - \\
\hline 9 & Peribadatan & $\begin{array}{c}\text { Fungsi } \\
\text { Perdagangan }\end{array}$ & 0,320 & Ya & $\begin{array}{l}\text { Kawasan } \\
\text { Budidaya }\end{array}$ & $\begin{array}{l}\text { Mengalami alih fungsi } \\
\text { namun kondisi } \\
\text { eksisting harus } \\
\text { dipertahankan. kondisi } \\
\text { eksisiting peribadatan } \\
\text { harus dipertahankan } \\
\text { karena dapat menjadi }\end{array}$ \\
\hline
\end{tabular}




\begin{tabular}{|c|c|c|c|c|c|c|}
\hline No & $\begin{array}{c}\text { Penggunaan } \\
\text { Lahan } \\
\text { Eksisting } \\
\end{array}$ & $\begin{array}{c}\text { Pola } \\
\text { Ruang } \\
\text { RDTR }\end{array}$ & Luasan & $\begin{array}{c}\text { Hasil } \\
\text { Overlay }\end{array}$ & Keterangan & $\begin{array}{c}\text { Dampak } \\
\text { Lingkungan }\end{array}$ \\
\hline & & & & & & $\begin{array}{l}\text { icon, sementara lokasi } \\
\text { sekitar tetap menjadi } \\
\text { fungsi perdagangan. } \\
\text { Dan jika kondisi } \\
\text { eksisting diubah } \\
\text { dikhawatirkan akan } \\
\text { menimbuklan konflik } \\
\text { sosial (agama). }\end{array}$ \\
\hline 10 & Perkantoran & $\begin{array}{c}\text { Fungsi } \\
\text { Perdagangan }\end{array}$ & 48,357 & Ya & $\begin{array}{l}\text { Kawasan } \\
\text { Budidaya }\end{array}$ & $\begin{array}{l}\text { Mengalami alih fungsi } \\
\text { namun tidak } \\
\text { menciptakan dampak } \\
\text { lingkungan }\end{array}$ \\
\hline 11 & Pendidikan & $\begin{array}{c}\text { Fungsi } \\
\text { Permukiman }\end{array}$ & 0,271 & Ya & $\begin{array}{l}\text { Kawasan } \\
\text { Budidaya }\end{array}$ & $\begin{array}{l}\text { Mengalami alih fungsi } \\
\text { namun kondisi } \\
\text { eksisting harus } \\
\text { dipertahankan }\end{array}$ \\
\hline 12 & $\begin{array}{l}\text { Perdagangan dan } \\
\text { Jasa }\end{array}$ & $\begin{array}{c}\text { Fungsi } \\
\text { Permukiman }\end{array}$ & 0,437 & Ya & $\begin{array}{l}\text { Kawasan } \\
\text { Budidaya }\end{array}$ & $\begin{array}{c}\text { Kondisi eksisting dan } \\
\text { pola ruang mengalami } \\
\text { alih fungsi dan } \\
\text { memberikan dampak } \\
\text { terhadap lingkungan, } \\
\text { fungsi perdagangan } \\
\text { dan jasa seharusnya } \\
\text { tidak diizinkan } \\
\text { didirikan di kawasan } \\
\text { permukiman karena } \\
\text { akan mengganggu } \\
\text { situasi yang kondusif } \\
\text { dan akan menimbulkan } \\
\text { dampak sosial seperti } \\
\text { konflik antara } \\
\text { masyarakat. Solusinya } \\
\text { perlunya } \\
\text { dipertahankan rencana } \\
\text { pola ruang kawasan } \\
\text { perdagangan dan jasa } \\
\text { diubah menjadi fungsi } \\
\text { permukiman }\end{array}$ \\
\hline 13 & Pergudangan & $\begin{array}{c}\text { Fungsi } \\
\text { Permukiman }\end{array}$ & 0,485 & Ya & $\begin{array}{l}\text { Kawasan } \\
\text { Budidaya }\end{array}$ & $\begin{array}{c}\text { Mengalami alih fungsi } \\
\text { dan menimbulkan } \\
\text { dampak lingkungan, } \\
\text { yaitu lahan memiliki } \\
\text { sifat tetap sementara } \\
\text { jumlah penduduk } \\
\text { semakin lama semakin } \\
\text { meningkat dan } \\
\text { membutuhkan lahan } \\
\text { permukiman yang } \\
\text { semakin besar } \\
\text { jumlahnya jika tidak } \\
\text { dikendalikan akan } \\
\text { menimbulkan dampak } \\
\text { sosial seperti timbulnya } \\
\text { kepadatan penduduk } \\
\text { ditahun-tahun yang } \\
\text { akan datang. }\end{array}$ \\
\hline 14 & Perkantoran & $\begin{array}{c}\text { Fungsi } \\
\text { Permukiman }\end{array}$ & 5,050 & Ya & $\begin{array}{l}\text { Kawasan } \\
\text { Budidaya }\end{array}$ & - \\
\hline 15 & $\begin{array}{c}\text { Sarana Pelayanan } \\
\text { Umum }\end{array}$ & $\begin{array}{c}\text { Fungsi } \\
\text { Permukiman }\end{array}$ & 1,743 & Ya & $\begin{array}{l}\text { Kawasan } \\
\text { Budidaya }\end{array}$ & $\begin{array}{c}\text { Mengalami alih fungsi } \\
\text { namun tidak } \\
\text { menyebabkan dampak } \\
\text { lingkungan, kondisi } \\
\text { eksisting harus } \\
\text { dipertahankan karena } \\
\text { merupakan fasilitas }\end{array}$ \\
\hline
\end{tabular}




\begin{tabular}{|c|c|c|c|c|c|c|}
\hline No & $\begin{array}{c}\text { Penggunaan } \\
\text { Lahan } \\
\text { Eksisting } \\
\end{array}$ & $\begin{array}{c}\text { Pola } \\
\text { Ruang } \\
\text { RDTR }\end{array}$ & Luasan & $\begin{array}{c}\text { Hasil } \\
\text { Overlay }\end{array}$ & Keterangan & $\begin{array}{c}\text { Dampak } \\
\text { Lingkungan }\end{array}$ \\
\hline & & & & & & $\begin{array}{c}\text { yang menunjang } \\
\text { kebutuhan masyarakat }\end{array}$ \\
\hline 16 & Perkantoran & $\begin{array}{c}\text { Fungsi } \\
\text { Permukiman }\end{array}$ & 0,001 & $\mathrm{Ya}$ & $\begin{array}{l}\text { Kawasan } \\
\text { Budidaya }\end{array}$ & - \\
\hline 17 & Sungai & Sungai & 3,290 & Tidak & $\begin{array}{l}\text { Kawasan } \\
\text { Lindung }\end{array}$ & - \\
\hline 18 & Sungai & Sungai & 0,333 & Tidak & $\begin{array}{l}\text { Kawasan } \\
\text { Lindung }\end{array}$ & - \\
\hline 19 & Pemakaman & $\begin{array}{l}\text { Fungsi } \\
\text { Lindung }\end{array}$ & 0,079 & Tidak & $\begin{array}{l}\text { Kawasan } \\
\text { Lindung }\end{array}$ & - \\
\hline 20 & Tegalan & $\begin{array}{l}\text { Fungsi } \\
\text { Lindung }\end{array}$ & 0,201 & Tidak & $\begin{array}{l}\text { Kawasan } \\
\text { Lindung }\end{array}$ & - \\
\hline 21 & Sungai & $\begin{array}{l}\text { Fungsi } \\
\text { Lindung }\end{array}$ & 5,801 & Tidak & $\begin{array}{l}\text { Kawasan } \\
\text { Lindung }\end{array}$ & - \\
\hline 22 & Tegalan & $\begin{array}{l}\text { Fungsi } \\
\text { Tegalan }\end{array}$ & 6,812 & Tidak & $\begin{array}{l}\text { Kawasan } \\
\text { Lindung }\end{array}$ & - \\
\hline 23 & Tegalan & $\begin{array}{l}\text { Fungsi } \\
\text { Tegalan }\end{array}$ & 0,108 & Tidak & $\begin{array}{l}\text { Kawasan } \\
\text { Lindung }\end{array}$ & - \\
\hline 24 & Sungai & Fungsi Sungai & 0,841 & Tidak & $\begin{array}{l}\text { Kawasan } \\
\text { Lindung }\end{array}$ & - \\
\hline 25 & Tegalan & $\begin{array}{l}\text { Fungsi } \\
\text { Tegalan }\end{array}$ & 0,246 & Tidak & $\begin{array}{l}\text { Kawasan } \\
\text { Lindung }\end{array}$ & - \\
\hline 26 & Tegalan & $\begin{array}{l}\text { Fungsi } \\
\text { Tegalan }\end{array}$ & 0,003 & Tidak & $\begin{array}{l}\text { Kawasan } \\
\text { Lindung }\end{array}$ & - \\
\hline 27 & Tegalan & Fungsi RTH & 0,003 & Tidak & $\begin{array}{l}\text { Kawasan } \\
\text { Lindung }\end{array}$ & - \\
\hline 28 & Kolam Renang & $\begin{array}{l}\text { Fungsi } \\
\text { Lindung }\end{array}$ & 0,117 & $\mathrm{Ya}$ & $\begin{array}{l}\text { Kawasan } \\
\text { Lindung }\end{array}$ & $\begin{array}{l}\text { Mengalami alih fungsi } \\
\text { namun tidak } \\
\text { menciptakan dampak } \\
\text { lingkungan }\end{array}$ \\
\hline 29 & Pendidikan & $\begin{array}{l}\text { Fungsi } \\
\text { Lindung }\end{array}$ & 0,388 & $\mathrm{Ya}$ & $\begin{array}{l}\text { Kawasan } \\
\text { Lindung }\end{array}$ & - \\
\hline 30 & $\begin{array}{l}\text { Perdagangan dan } \\
\text { Jasa }\end{array}$ & $\begin{array}{l}\text { Fungsi } \\
\text { Lindung }\end{array}$ & 4,547 & $\mathrm{Ya}$ & $\begin{array}{l}\text { Kawasan } \\
\text { Lindung }\end{array}$ & - \\
\hline 31 & Peribadatan & $\begin{array}{l}\text { Fungsi } \\
\text { Lindung }\end{array}$ & 0,055 & $\mathrm{Ya}$ & $\begin{array}{l}\text { Kawasan } \\
\text { Lindung }\end{array}$ & - \\
\hline 32 & Perkantoran & $\begin{array}{l}\text { Fungsi } \\
\text { Lindung }\end{array}$ & 8,037 & $\mathrm{Ya}$ & $\begin{array}{l}\text { Kawasan } \\
\text { Lindung }\end{array}$ & - \\
\hline 33 & Jalan & $\begin{array}{l}\text { Fungsi } \\
\text { Lindung }\end{array}$ & 7,598 & $\mathrm{Ya}$ & $\begin{array}{l}\text { Kawasan } \\
\text { Lindung }\end{array}$ & - \\
\hline 34 & Jalan Tol & $\begin{array}{l}\text { Fungsi } \\
\text { Lindung }\end{array}$ & 0,018 & $\mathrm{Ya}$ & $\begin{array}{l}\text { Kawasan } \\
\text { Lindung }\end{array}$ & - \\
\hline 35 & Perkantoran & Fungsi RTH & 0,121 & $\mathrm{Ya}$ & $\begin{array}{l}\text { Kawasan } \\
\text { Lindung }\end{array}$ & - \\
\hline 36 & Tegalan & Fungsi RTH & 4,956 & Tidak & $\begin{array}{l}\text { Kawasan } \\
\text { Lindung }\end{array}$ & - \\
\hline 37 & $\begin{array}{l}\text { Perdagangan dan } \\
\text { Jasa }\end{array}$ & $\begin{array}{l}\text { Fungsi } \\
\text { Lindung }\end{array}$ & 3,821 & $\mathrm{Ya}$ & $\begin{array}{l}\text { Kawasan } \\
\text { Lindung }\end{array}$ & - \\
\hline 38 & Perkantoran & $\begin{array}{l}\text { Fungsi } \\
\text { Lindung }\end{array}$ & 0,001 & $\mathrm{Ya}$ & $\begin{array}{l}\text { Kawasan } \\
\text { Lindung }\end{array}$ & - \\
\hline
\end{tabular}

Berdasarkan hasil analisis yang dilakukan, diperoleh hasil bahwa dari luas lahan kawasan sebesar $123.938 \mathrm{Ha}$, terjadi pergeseran perubahan peruntukan sebanyak $65,80 \%$ dengan luas 81.539 Ha yang didominasi oleh kegiatan permukiman, perdagangan dan jasa (lihat Gambar 2). Hal ini akan memberikan pengaruh yang sangat besar terhadap kondisi perairan kalimalang, karena semua limbah domestik dan non domestik yang dihasilkan oleh masyarakat yang tinggal di kawasan ini dibuang langsung ke Kalimalang. 


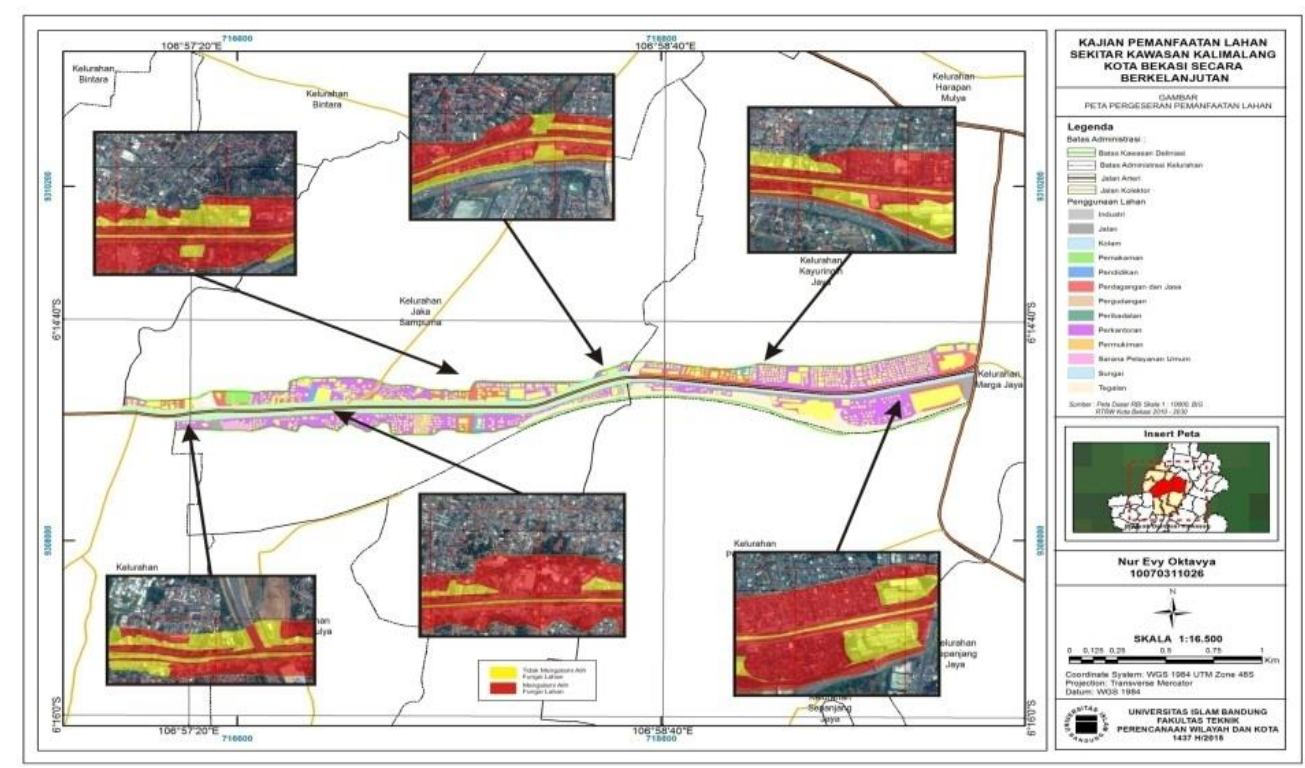

Gambar 2 Peta Pergeseran Peruntukan Lahan di Kawasan Kalimalang

\section{Analisis Mata Pencaharian}

Setelah melakukan analisis mata pencaharian terlihat jumlah penduduk yang bekerja sebanyak $\mathbf{2 . 9 6 8}$ jiwa. Penduduk di kawasan Kalimalang lebih banyak bekerja sebagai wirausaha 1.052 $(35.44 \%)$ yaitu mayoritas sebagai pedagang pengusaha barang bekas, kayu dan kegiatan lainnya. Jika swasta 1.034 $(34.84 \%)$ ialah sebagai karyawan swasta kemudian sebagai buruh pabrik 697 $(23.48 \%)$. Sementara penduduk yang bekerja sebagai Pegawai Negeri Sipil, polisi dan militer tidak begitu mendominasi, penduduk yang bekerja sebagai pegawai negeri sipil 128 jiwa (4.31\%) kemudian polisi dan militer 57 jiwa (1.92\%).

\section{Analisis Tingkat Pendidikan}

Jika melihat hasil persentase jumlah penduduk menurut tingkat pendidikan diatas didapatkan hasil jumlah penduduk terbanyak yang tamat menjalankan pendidikan ialah tamatan sekolah menengah atas (SMA) sebanyak 2.632 jiwa $(54,27 \%)$ sementara tertinggi kedua ialah tamatan perguruan tinggi didapatkan hasil 983 jiwa $(20.27 \%)$ sedangkan yang terendah ialah tamatan sekolah dasar (SD) sebanyak 54 jiwa $(1.11 \%)$. Hal ini tentunya menjadi faktor penyebab pembangunan-pembangunan disekitar kawasan Kalimalang karena dipengaruhi oleh pola pemikiran masyarakat yang beragam. Jika melihat hasil analisis kualitas sumber daya masyarakat kawasan Kalimalang cukup tinggi karena mayoritas memiliki pendidikan ditingkat sekolah menengah atas.

Analisis Hubungan Pembangunan di Kawasan Kalimalang dengan Penyebabnya

Analisis ini bertujuan untuk melihat korelasi antara kegiatan pembangunan di Kawasan Kalimalang dengan kondisi sosial masyarakat mancakup pendapatan masyarakat dengan aksesibilitas ke tempat bekerja masyarakat. Dengan menggunakan analisis korelasi kontingensi diperoleh hasil bahwa kegiatan pembangunan atau pemanfaatan lahan di Kawasan Kalimalang mempunyai korelasi positif dengan pendapatan masyarakat dan tingkat aksesibilitas masyarakat ke tempat bekerja. Hal disebabkan karena 
Kawasan Kalimalang mempunyai lokasi yang sangat strategis menuju ke lokasi tempat kerja di Kota Bekasi, karena semua jalur angkutan umum melewati kawasan ini. Di samping itu juga masyarakat cenderung membangun di kawasan ini, karena lahan pada kawasan ini merupakan lahan milik Pemerintah Daerah, sehingga masyarakat dapat dengan mudah memeperoleh dan menggunakan lahan tersebut karena kurangnya pengawasan pemanfaatan lahan oleh Pemerintah Daerah Kota Bekasi. Hal ini mengakibatkan pertumbuhan pembangunan khususnya untuk kegiatan permukiman dan jasa cukup tinggi pada kawasan ini, sehingga mengakibatkan penurunan kualitas lingkungan khususnya pada kondisi perairan Kalimalang. Sementara disisi lain air Kalimalang dimanfaatkan sebagai sumber air baku untuk memenuhi kebutuhan akan air bersih di Kota Bekasi. Melihat pada kondisi ini, pengendalian pemanfaatan lahan di kawasan ini sangat dibutuhkan dan harus disesuaikan dengan peruntukan dan daya dkung serta daya tampung lahannya, agar dapat mewujudkan pemanfaatan lahan berkelanjutan di kawasan ini.

Analisis Intensitas Bangunan

Suatu bangunan tentunya diharuskan memiliki lahan resapan air yang berguna untuk menghindari banjir dan penyediaan ruang terbuka hijau (RTH). Kondisi permukiman disekitar Kalimalang seharusnya memiliki koefisien dasar bangunan (KDB) yang sesuai namun pada kenyataanya hal tersebut tidak sesuai bahkan hampir semua bangunan yang berada di Kawasan Kalimalang melanggar ketentuan koefisien dasar bangunan. Koefisien dasar bangunan yang sesuai dengan standar ialah memiliki koefisien dasar bangunan sebesar $60 \%$ sementara permukiman disekitar Kalimalang memiliki koefisien dasar bangunan >
60\%. Ha ini mengakibatkan berkurangnya kawasan yang berfungsi untuk resapan air, sehingga pada waktu hujan aliran run off semakin besar, yang mengakibatkan banjir di kawasan. Untuk mengantisipasi hal tersebut perlu difungsikan peruntukan lahan di kawasan kalimalang dengan melakukan keseimbangan antara peruntukan kawasan terbangun dengan kawasan non terbangun, sehingga kondisi lingkungan dapat menjadi baik.

\section{Kesimpulan dan Rekomendasi}

Dari penelitian yang dilakukan, dapat disimpulkan mengenai hasil kajian pengendalian pemanfaatan lahan di Kawasan Kalimalang sebagai berikut :

Pertama, Kawasan Kalimalang memiliki luas lahan sebesar $123.938 \mathrm{Ha}$, mengalami pergeseran alih fungsi lahan sebanyak $65,80 \%$ dengan luas 81.539 Ha yang didominasi oleh kegiatan permukiman, perdagangan dan jasa. Sementara yang tidak mengalami pergeseran ialah $34,20 \%$ dengan luas $42.389 \mathrm{Ha}$.

Kedua, Pada umumnya masyarakat di Kawasan Kalimalang memiliki mata pencaharian di sektor perdagangan dan jasa seperti : sebagai pedagang, pengusaha barang bekas, kayu dan karyawan swasta.

Ketiga, Kawasan studi memiliki tingkat aksesibilitas masyarakat yang tinggi untuk bepergian ketempat kerja, bersekolah dan kegiatan lainnya.

Keempat, Penggunaan lahan dipengaruhi oleh aksesibilitas dan tingkat pendapatan yang menyebabkan penyimpangan penggunaan lahan.

Kelima, Tidak adanya lahan konservasi di kawasan Kalimalang.

Keenam, $65.8 \%$ permukiman ilegal yang dibangun dipinggiran Kalimalang Kota Bekasi yang berdampak mengurangi estetika kota dan tidak sesuai dengan standar koefisien dasar 
bangunan (KDB). Koefisien dasar bangunan di Kawasan Kalimalang > $60 \%$ bahkan $100 \%$.

Berdasarkan hasil kajian yang dilakukan dari penelitian ini, beberapa hal yang dapat direomendasikan untuk dapat mewujudkan kondisi pemanfaatan lahan agar sesuai dengan peruntukkannya dalam rangka mewujudkan pemanfaatan lahan berkelanjutan di kawasan kalimalang, adalah sebagai berikut :

Pertama, Memfungsikan Kawasan Kalimalang yang menjadikan ruang terbuka hijau (RTH) sebagai kawasan lindung

Kedua, Penertiban tata guna lahan di sepanjang Kalimalang

Ketiga, Merelokasi masyarakat yang tinggal di Kawasan Kalimalang

Keempat, Menyediakan rumah susun sederhana sewa (rusunawa)

Kelima, Arahan pemanfaatan lahan yang direkomendasikan dari hasil kajian ini sebagaimana dapat dilihat pada gambar berikut.

\section{Daftar Pustaka}

Moekijat, 1980, Kamus Management, Alumni, Bandung

Barnett, Jonathan 1982. Introduction to Urban Design. New York: Harper \& Row Publishers.

Brundtland Report, 1987, Our Common Future. Oxford University Press, Oxford

Undang-Undang Nomor 26 Tahun 2007

Tentang Penataan Ruang

Rencana Detail Tata Ruang (RDTR)

Kota Bekasi 2011 - 2031 